\title{
Respecting the Order and Liberty of Deliberations
}

\author{
Continuity of Meeting Practices in the Dutch States General
}

(c. 1750-1830)

\author{
LAUREN LAURET
}

Between 1815 and 1830 Northern and Southern members of the States General clashed over how to behave as political representatives. This article presents this conflict as evidence of the continuity of the meeting practices employed in the States General since the Dutch Republic. Examples from three different periods show the continuity of three elements of the Northern meeting practice. Pragmatic, secluded and dignified meetings aimed at achieving consensus among the provinces or among members, Chamber, king and government. Deliberations on a resolution or a bill had to take place in an orderly and harmonious manner to ensure the willingness of the provinces or the Dutch people to obey the law. Hence, the political legitimacy of the state was constantly at stake during sessions of the States General and directly connected with correct procedure and behaviour. The continuity of the three practical elements nuances the impact of the constitutional ruptures which on first sight clearly separate the States General of the Dutch Republic from its successor in the United Kingdom of the Netherlands.

Tussen 1815 en 1830 botsten Noordelijke en Zuidelijke Leden van de StatenGeneraal over hoe zij zich als volksvertegenwoordigers dienden te gedragen. Aan de hand van de weergave van deze botsing toont dit artikel de continuïteit aan van een vergaderpraktijk die ontwikkeld werd in de Staten-Generaal in de Republiek der Zeven Verenigde Nederlanden en die ondanks verschillende constitutionele verschuivingen gangbaar bleef. Voorbeelden afkomstig uit drie politiek verschillende tijdvakken tonen de continuïteit van drie elementen in de dominante 
Noordelijke vergadermores. Zakelijke, besloten en eerbiedwaardige vergaderingen en vergaderaars streefden naar consensus tussen de provincies of tussen de leden, Kamer, koning en regering. Het ordentelijke en harmonieuze overleg in de StatenGeneraal was een voorwaarde voor de gehoorzaamheid van provincies en burgers aan de uitgevaardigde Resoluties of wetten. De politieke legitimiteit van de staat stond altijd op het spel in de vergadering en hield direct verband met de correcte vergaderprocedure en passend gedrag. De continuïteit van de drie praktische elementen nuanceert de impact van de constitutionele breuken die de StatenGeneraal van de Republiek op het eerste gezicht zo duidelijk onderscheiden van hun naamgenoot in het Verenigd Koninkrijk der Nederlanden.

During budget talks in December 1821, H.A.J. Liefmans (1781-1851), a lawyer from the Southern half of the Netherlands, asked rhetorically why it was impossible to criticise certain elements of a bill without immediately being accused of rebellion against king and country. ${ }^{2}$ In an earlier intervention in the Second Chamber the year before, Liefmans had defended his style of fierce and open opposition. By no means was his choice of words the product of an oppositional spirit. Had he formulated his opinion this sharply as a common citizen, it would have been out of place. As a representative of the nation, however, Liefmans could not contain himself and felt obliged to speak out vigorously. ${ }^{3}$ His Southern colleague Charles le Hon (1792-1868) was equally well aware that the code of conduct required him to refrain from detailed and passionate reasoning and instead urged Le Hon to display restrained detachment in order to enhance the solemnity of discussions. ${ }^{4}$ Nevertheless, Le Hon could not believe his ears when his Northern colleague Van Alphen complained about the heated atmosphere during debates on the budget

would like to thank Els Witte, Jeroen van Zanten, and the Cluster Staat (Huygens ING) for sharing their expertise during the research for this article. I would like to thank Joris Oddens in particular for his helpful comments on an earlier version of this article. 22 December 1821, 48. 'Eh quoi! Ne peut-on combattre quelques dispositions d'un code ou d'un système financier sans être mis au rang des séditieux?' plaise, mes honorables collègues, que quelqu'un de vous croie que je veuille, en m'exprimant d'une manière si ouverte, marquées du sceau de

mon improbation le vote émis par la majorité;

$[\ldots]$ Ils auraient pu captiver mon opinion comme simple citoyen; mais comme représentant de la nation j'ai cru ne pouvoir me borner à m'y reposer.' HTK 1826-1827, 30 January 1827,122 . '[J]e sais, que ce qui intéresse surtout une province, c'est d'être représentée par des hommes de confiance et de son choix, et que ce qui est de la dignité de la Chambre, c'est de se montrer supérieure aux menées des petits intérêts, des petites passions, c'est de se donner une grande latitude, et surtout d'apporter de la maturité dans l'examen et de la solennité dans la discussion.' 
in 1829. Le Hon fumed over how vigorously defending the rights and dignity of the Second Chamber could be regarded as anything but respecting the order and liberty of deliberations. ${ }^{5}$ Liefmans' and Le Hon's remarks directed at the hostile attitudes of their Northern colleagues provide the research question for this article. Why did Northern members find vigour and passion harmful to the dignity and legitimacy of the meeting of the States General?

After the Congress of Vienna, the Kingdom of the Netherlands came to include the former Austrian territories. The Restoration States General had to accommodate the additional 55 members representing the citizens living in the Southern Provinces. ${ }^{6}$ The Constitutional Committee mainly looked at French and British examples to arrange the parliament for the enlarged Kingdom of the Netherlands. When the Restoration States General met in their new constitutional setting, Northern and Southern members clashed over how to behave.

The reason for this conflict should be sought in the early modern roots of the States General. ${ }^{7}$ This feels counterintuitive because at first sight the divide between the Old Regime States General and its Restoration namesake seems absolute. The Restoration States General represented the entire Dutch people in a constitutional monarchy. It served as a legislative assembly which could only approve or reject bills proposed by the king or his ministers. The States General of the Dutch Republic comprised a meeting of delegates bound by instructions of their sovereign Provincial States. Lacking a written constitution, meetings of the early modern States General provided the stage where the delegations of the seven sovereign provinces performed their main task: negotiating common policies on matters concerning war, peace, foreign affairs and finance. ${ }^{8}$

Dutch historians have, however, already nuanced the idea of clean political ruptures following the regime changes since the abolition of the Dutch Republic in $1795 .{ }^{9}$ The Restoration States General was neither an grande, oui, mais n'était-elle pas légitime? $[\ldots]$ Défendre avec chaleur les droits et la dignité de la Chambre, n'est-ce pas respecter et vouloir qu'on respecte l'ordre et la liberté de ses délibérations?' Koninkrijk der Nederlanden (1815-1830) en het ontstaan van de Belgische Constitutie (1831)', in: André Alen et al. (eds.), De Grondwet van het Verenigd Koninkrijk der Nederlanden van 1815. Staatkundige en historische beschouwingen uit België en Nederland (Amsterdam 2015) 15-44, see 18-24.
Republic', International Review of Administrative Sciences 76:1 (2010) 47-64, see 47-48. DOI: https:// doi.org/10.1177/0020852309359044.

8 Olaf Mörke, 'Kohärenzstiftung durch Verfahren im partikularisierten Staat. Die Generalstände in der niederländischen Republik', in: Barbara Stollberg-Rilinger (ed.), Vormoderne politische Verfahren (Berlin 2001) 521-557, see 539, 553-555.

9 Ido de Haan, Politieke reconstructie. Een nieuw begin in de politieke geschiedenis (inaugural lecture, Utrecht University, 12 March 2004) 7, 12; Matthijs Lok, Windvanen. Napoleontische bestuurders in de Nederlandse en Franse restauratie (1813-1820) (Amsterdam 2009) 29, 217-225. 
entirely new institution, nor was it an exact copy of its historical namesake. ${ }^{10}$ Instead, since 1815 the Restoration States General combined old elements - such as its name - with undeniable new elements, such as bicameralism, public debates of the Second Chamber and elected members who represented both the Northern and Southern provinces of the Low Countries. In order to grasp the composite political culture of the Restoration States General, it is necessary to understand which early modern elements of the States General survived the regime changes, why those elements survived, and what the consequences were of this continuity of practices.

\section{Early modern political meetings}

The European early modern political world was hierarchical and fundamentally unequal. Early modern political meetings represented the correct distinctive order of society. ${ }^{11}$ Physical presence, be it through participation or observation, was a prerequisite for the correct order to be acknowledged as an existing reality. This explains why early modern society was about 'communication among those who were present'. ${ }^{12}$ The repetitive gathering in an early modern political meeting presented the state as an objective and legitimate political reality. ${ }^{13}$ Inappropriate behaviour in this

Republiek naar constitutioneel koninkrijk, 17801848', in: idem (eds.), Land van kleine gebaren. Een politieke geschiedenis van Nederland 1780-2012 (Amsterdam 2013) 76-78; Remieg Aerts, Carla van Baalen and Henk te Velde, 'Tweehonderd jaar Tweede Kamer', in: idem (eds.), In dit Huis. Twee eeuwen Tweede Kamer (Amsterdam 2015) 13-37, see 19; Niek van Sas, 'De representatieve fictie. Politieke vertegenwoordiging tussen oude orde en moderniteit', Bijdragen en Mededelingen betreffende de Geschiedenis der Nederlanden 120:3 (2005) 397407, see 403; Matthijs Lok, “'Un Oubli Total Du Passé"? The Political and Social Construction of Silence in Restoration Europe (1813-1830)', History E Memory 26:2 (2014) 40-75, see 50; Joris Oddens, Pioniers in schaduwbeeld. Het eerste parlement van Nederland 1796-1798 (Nijmegen 2013) 14. Marian Füssel and Thomas Weller (eds.), Ordnung und Distinktion. Praktiken der sozialen
Repräsentation in der ständischen Gesellschaft

(Münster 2005) Introduction: 9-22, see 9-10; Barbara Stollberg-Rilinger, 'Symbolische Kommunikation in der Vormoderne. Begriffe Thesen - Forschungsperspektiven', Zeitschrift für historische Forschung 31:4 (2004) 489-528, see 493-496.

12 Rudolf Schlögl, 'Kommunikation und Vergesellschaftung unter Anwesenden', Geschichte und Gesellschaft 34:2 (2008) 155224, see 183-191. DOI: https://doi.org/10.13109/ gege.2008.34.2.155

13 Barbara Stollberg-Rilinger, The Emperor's Old Clothes: Constitutional History and the Symbolic Language of the Holy Roman Empire (New York and Oxford 2015) 11; contemporaries compared the meeting of the States General to the Reichstag of the Holy Roman Empire. François Janiçon, De Republiek der Vereenigde Nederlanden. Deel I (The Hague 1736) 131. 


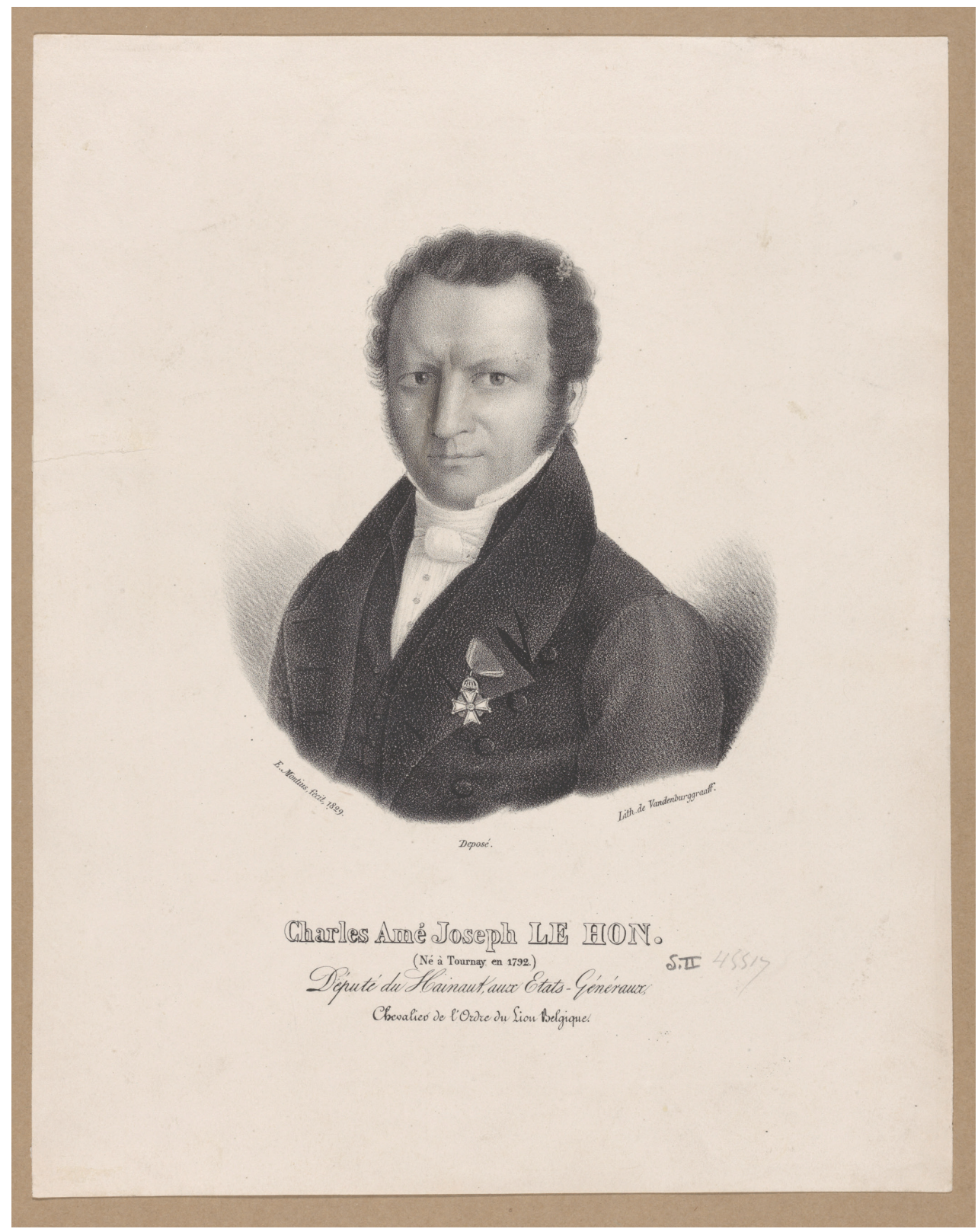

$\Delta$

Charles le Hon (1781-1851), member of the States General on behalf of Limburg. Royal Library of Belgium, Brussels. 
symbolically charged setting was immediately linked to disrespect for the political dignity that the political meeting and its participants represented. ${ }^{14}$

Since the cultural turn in political history the question of why people performed their political actions in a certain way has intrigued political historians. ${ }^{15}$ Human actions, habits and communication are the core of every political space, regardless of the time period. ${ }^{16}$ There has been within political history a shift of attention away from short-term political events and towards the underlying layer of political culture which is characterised much more by continuity. ${ }^{17}$ In recent years, historians of political culture have started to consider parliaments as communicative spaces in order to do justice to the symbolically charged political communication taking place during sessions. ${ }^{18}$ Parliamentary politics in particular revolved around unspoken conventions or 'rules of the game'. ${ }^{19}$ Existing studies on the Dutch parliament in later periods have shown the importance of paying attention to the deeper layer of unspoken political mores in the political culture of this institution. ${ }^{20}$ Moreover, these studies have proven that studying this institution's political culture is necessary for understanding the political events embedded in this culture. This article combines these notions on early modern political meetings and the political culture of parliaments in general and applies them to the long-term history of the States General.

This means that the way members of the States General behaved (or at least were supposed to behave) contributed to the political legitimacy Appropriateness', in: Robert Goodin, Michael Moran and Martin Rein (eds.), The Oxford Handbook of Public Policy (Oxford 2008) 690-708, see 692. and Heinz-Gerhard Haupt (eds.), Neue Politikgeschichte. Perspektiven einer historischen Politikforschung (Frankfurt and New York 2005) 7-26, see 24 .

Wilbert van Vree, Manners and Civilisation. The Development of Modern Meeting Behaviour (Leicester 2001); Norbert Elias, Die höfische Gesellschaft. Untersuchungen zur Soziologie des Königtums und der höfischen Aristokratie (Darmstadt 1969).

\footnotetext{
cultuur', in: Hans Righart (ed.), De zachte kant van de politiek. Opstellen over politieke cultuur (The Hague 1990) 11-26, see 16,19 .

Hans Righart, 'Politieke geschiedenis en politieke
}

James March and Johan Olsen, 'The Logic of Ute Frevert, 'Neue Politikgeschichte. Konzepte und Herausforderungen', in: Ute Frevert

18 Andreas Schulz and Andreas Wirsching (eds.), Parlamentarische Kulturen in Europa. Das Parlament als Kommunikationsraum (Düsseldorf 2012) 17; Delphine Gardey, Le Ligne du Palais Bourbon. Corps, matérialité et genre du politique à l'ère démocratique (Lormont 2015) 9-16. 
of the Dutch state. Every political regime partly relied on meetings of the States General for its legitimacy, irrespective of the historical period. Meeting practices in turn supported the legitimacy of the States General's claim to function as the prime meeting in government. This interplay between political practices and legitimacy explains why the States General paid close attention to its meeting practice in the first place, but even more why meeting practices mattered for a Restoration regime in pursuit of legitimacy. Participants in meetings did not passively inherit a set of meeting practices. Instead, members of the States General consciously chose to act and to behave in a certain way even though they had alternative options. An institutional tradition requires human action in order to be handed down. ${ }^{21}$ That is why shifting the perspective towards meeting practices reveals continuity rather than change between early modern and modern practices of political representation.

Moments of conflict forced participants to address the otherwise unspoken rules of the game. Traces of conflict situations are scarce, however, in the official archives of the States General because of the nature of the surviving records. Since the assembly always sought to give the impression of harmonious conduct, the resolutions of the States General contain minimal information on the preparation of the decisions that were eventually adopted. No official evidence remains of the debates prior to that point. ${ }^{22}$ This omission of conflict in official records was typical for early modern administration. ${ }^{23}$ Valuable exceptions exist where the meeting's secretary-griffier-documented two situations of conflict verbatim and kept the records in his personal archive. ${ }^{24}$ These conflicts are presented here to reveal the unspoken norms and values guiding the behaviour of the provincial delegates. The Restoration States General continued to keep session records to a minimum and, above all, the meeting stuck to the principle of not recording personal opinions despite multiple requests to do so. ${ }^{25}$ Hence, after 1814 the official archive of the States General shows little evidence of discord. Fortunately for the historian, during the third quarter of the nineteenth century, Jan Noordziek (1811-1886)

\section{Traditions. Culture, Agency and Power', in: idem} (eds.), Tradition and Agency (Aarhus 2005) 11-55, see 33,36 .

\footnotetext{
Theo Thomassen, Onderzoeksgids. Instrumenten van de macht. De Staten-Generaal en hun archieven 1576-1796. Band I (The Hague 2015) 202-204.

Joke Roelevink, 'Dit moet maar niet in de notulen... De invloed van onderwerpen, voorzichtigheid en conflicten op de classicale verslaglegging tot 1620', Tijdschrift voor
}

\footnotetext{
Nederlandse Kerkgeschiedenis 19:2 (2016) 48-55; The exception being the British House of Commons: Jason Peacey, 'Disorderly Debates: Noise and Gesture in the 17th-Century House of Commons', Parliamentary History 32:1 (2013) 61-78, see 62-65. 
undertook the impressive task of meticulously reconstructing the debates between 1814 and 1847 based on official documents, newspaper reports and personal parliamentary papers. ${ }^{26}$

In order to illustrate that the meeting practices of the States General in the Dutch Republic continued after 1795, I will focus on the idea of symbolic political quality: meetings functioned as a resource for the political dignity and legitimacy of the Dutch state as a whole because sessions were the place where the right power balance between personal honour and political dignity and legitimacy had to be maintained. I have identified three elements that served to fulfil this objective of the States General. The first element is the state of mind, or style, which accommodated the meeting's laborious task. The desired atmosphere of the meeting is best described as pragmatic. Divergent opinions were acceptable although opposition for the sake of opposition was regarded as fruitless in negotiations. ${ }^{27}$ Small committees brokered majorities before the deciding plenary sessions. ${ }^{28}$ Delegates who brought reasonable arguments to the table, presented in a quiet manner, were better able to gather a majority than those who defended their position with vigour and passion. The strong voice of one provincial delegate could hardly have the common interest of the Republic at heart. Secondly, seclusion and small-scale settings best fitted the purpose and mind-set of the States General, even though a secluded meeting might seem to provide for the opportunity to disagree on something out of the public eye. Yet, even behind closed doors Dutch regents aimed for calm and effective deliberations, rather than lively debates. Through his physical attendance of the States General, every delegate represented both his provincial and personal dignity. ${ }^{29}$ The third element therefore concerns what was at stake for delegates and members: properly fulfilling their tasks as representatives contributed to their personal honour. ${ }^{30}$ The remainder of the article discusses examples taken from meeting practices in the Old Regime States General, the Batavian parliaments and the Restoration States General to demonstrate this continuity.

Carla van Baalen and Eric Tanja, 'In dienst van de Kamer. De ambtelijke ondersteuning van de volksvertegenwoordigers', in: Aerts, In dit Huis, 193-222, 198-199, 209.

Frederik Krämer (ed.), Gedenkschriften van Gijsbert

Jan van Hardenbroek. Werken uitgegeven door het Historisch Genootschap. Derde serie, nr. 14 (Amsterdam 1901) Deel II, 150, 160, 163, 185. See also: Jeroen van Zanten, Schielijk, Winzucht, Zwaarhoofd en Bedaard. Politieke discussie en oppositievorming 1813-1840 (Amsterdam 2004) 274-295.
28 Jos Gabriëls, De heren als dienaren en de dienaar als heer. Het stadhouderlijk stelsel in de tweede helft van de achttiende eeuw (The Hague 1990) 307-308.

29 Ibidem, 321.

30 Jörg Feuchter and Johannes Helmrath, 'Oratory and Representation: The Rhetorical Culture of Political Assemblies, 1300-1600', Parliaments, Estates and Representation 29:1 (2009) 53-66, see 62-65; compare with Joanne Freeman, Affairs of Honor. National Politics in the New Republic (New Haven and London 2001). 


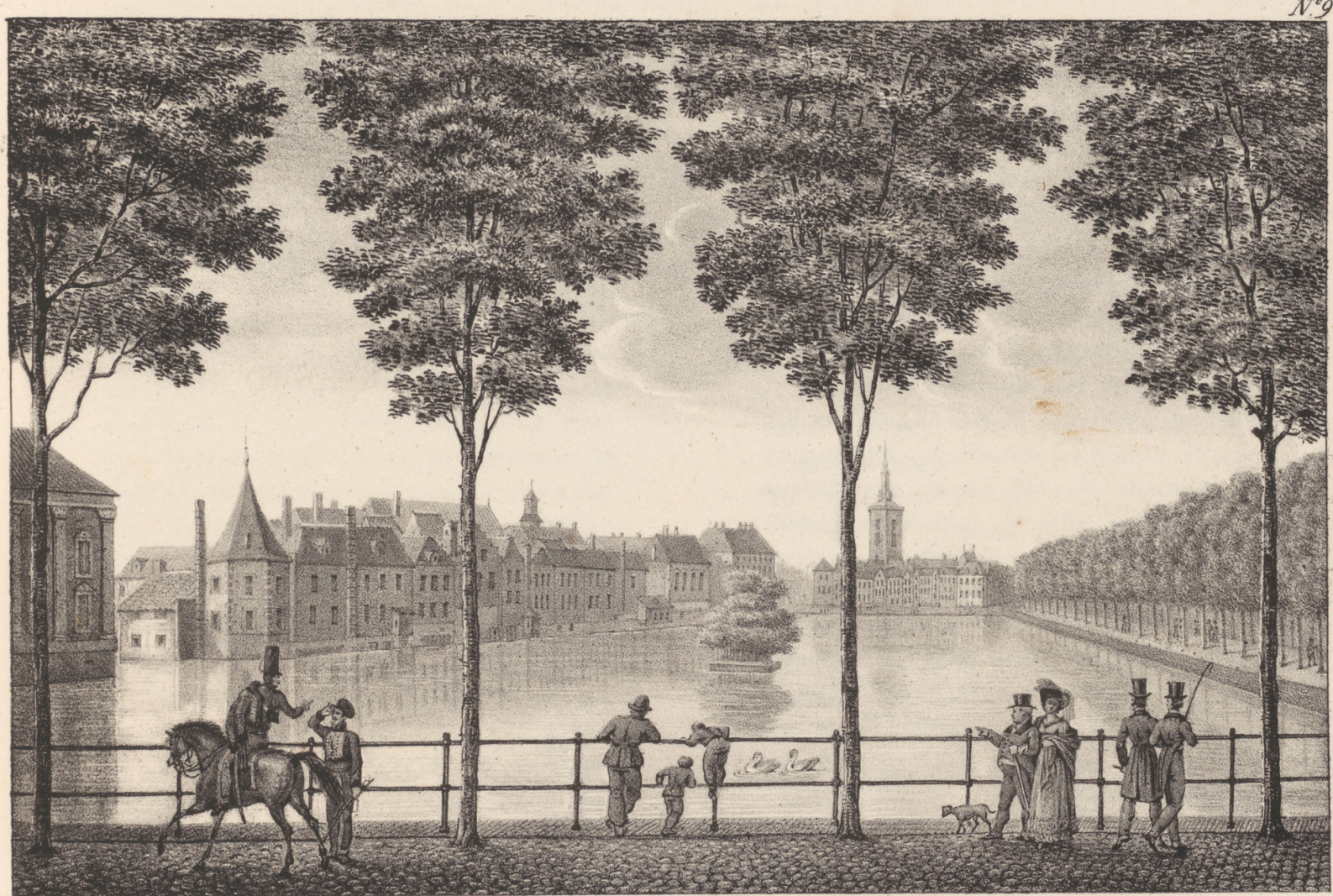

$$
\text { True du Tyverberg a la Hoyge. }
$$

View of the Binnenhof and Hofvijver in The Hague. Printed in J.J. de Cloet, Voyage pittoresque dans le Royaume des Pays-Bas (Brussels 1825). Royal Library of Belgium, Brussels. 


\section{Dutch Republic}

The States General sanctioned resolutions in a secluded plenary session..$^{31}$ The assembly wanted to convey unity and harmony outside its quarters at the Binnenhof in The Hague. In any pre-modern representative assembly adhering to correct procedure of decision-making ensured that all parties acknowledged the final decision and that they would obey it in the future. ${ }^{32}$ This assurance of obedience was especially important for the Dutch Republic. The cooperation among the provinces rested on their voluntary accession to the Union of Utrecht. ${ }^{33}$ Conflict situations nevertheless occurred and they illustrate the kinds of procedures the States General was looking for in its everyday business. The first conflict presented here illustrates how a calm atmosphere (1) and personal honour (3) supported the balance of power in the States General.

Harmony and unity disappeared when a deputy dared to question the procedure surrounding a resolution, drafted on 19 May 1744, following a proposition by Holland. ${ }^{34}$ Frisian deputy Adrianus Bergsma claimed that griffier François Fagel's draft did not fully reflect all seven provincial positions. To prove his point Bergsma requested the original proposition. The reactions to his request illustrate its inappropriateness. Grand Pensionary Anthonie van der Heim (1693-1746) attempted to protect the formal atmosphere. He reminded Bergsma to speak on behalf of his provincial States. ${ }^{35}$ Friesland had to authorise Bergsma to request Holland's proposition. But after this attempt to dismiss the matter, the other delegates lost their composure. Twice the president had to use his hammer to restore order among the deputies. Finally, the president asked each provincial speaker for his position on this matter to put an end to the discussion and to allow deputies to restore the provincial order. During this round Holland's deputies employed their authority to frustrate Bergsma's efforts. They called on the Frisian deputation to keep their fellow deputy in check. ${ }^{36}$ Faced with this forceful display of hierarchy,

Gabriëls, De heren als dienaren, 299-310.

Jacob Burckhardt, 'Procedure, Rules and Meaning

of Political Assemblies in Late Medieval Central

Europe', Parliaments, Estates and Representation

35:2 (2015) 153-170, see 159-16o. DoI: https://doi.or

g/10.1080/02606755.2015.1023666.

Simon van Slingelandt, 'Discours over de defecten

in de jegenswoordige Constitutie der Regeering

van den Staat der Vereenigde Nederlanden

[...]' (1716), in: Idem, Staatkundige geschriften ।

(Amsterdam 1784) 171-314, see 186-187.

NL-HaNA, Fagel, 1.10.29, inv. nr. 582 'Incident

Bergsma' in de vergadering der Staten-Generaal.
Oude en aantekeningen van Hendrik Fagel de Oude, 1744; Nicolaas Japikse, 'De Staten-Generaal in de achttiende eeuw (1717-1795)', in: Sybrand Fockema Andreae and Herman Hardenberg (eds.), 500 jaren Staten-Generaal in de Nederlanden (Assen 1964) 99-141, see 111-115. Wim Dral, Tussen macht en onmacht. Een politieke biografie van Anthonie van der Heim (1693-1746) (Hilversum 2016) 172-173, 186-187.

36 NL-HaNA, Fagel, 1.10.29, inv. nr. 582. Bergsma: 'weer tegen den Raadpensionaris die weer iets wilde seggen. Ik ben niet gehouden aan $\mathrm{U}$ te antwoorden. Ik ben voor eenige dagen sanglant door Rhoon geattaqueert, wanneer hij tot mijn 
Bergsma grudgingly withdrew his request. He did regret, however, that his questioning of the resolution had put Fagel's reputation in jeopardy. For that reason he wrote an extensive apology which Fagel carefully kept in his archive as testimony to his professional and personal honour. In his reply, Fagel entrusted Bergsma with his thoughts on the incident. Of course, his good name was not irrelevant to him. But it had hurt Fagel more to see how, needlessly, Bergsma's conduct had caused dispute and discord among the deputies, had aroused passion and had harmed the commonweal as a result. ${ }^{37}$

Even though Bergsma's question seemed at first sight to be merely an inappropriate personal request, it immediately gave rise to a reaffirmation of the hierarchy among deputies and to a display of their composure. Personal wishes and passionate pleas were out of place in meetings of the States General. Besides dealing with matters of state, deputies were constantly preoccupied with observing each other's gestures and weighing every word and phrase on the scale of personal honour and political dignity. ${ }^{38}$

The second known incident occurred shortly after the unexpected death of stadtholder William IV of Orange (1711-1751) and was caused by Frisian deputy Tjerd van Aylva. Van Aylva was a merry man with a habit of lavish dining and drinking in the company of prostitutes and actresses, or so Utrecht deputy Gijsbert Jan van Hardenbroek recorded in his diary. ${ }^{39}$ The incident shows that composed behaviour (1) mattered even in the everyday secluded confinements (2) of the States General's preparatory sessions. Additionally, the incident sheds light on the all-encompassing importance of personal honour (3) and how the plenary session was the place where the balance between personal honour and political stability was at stake.

Shortly before he died, Stadtholder William Iv had sent a proposition to the States General concerning financial support for the military. The deputies of Overijssel refused to give their consent. Frisian deputy Tjerd van Aylva reacted to this refusal in unacceptably common and careless language. Encouraged by the familiar atmosphere during the meeting, Van Aylva equalled Overijssel's refusal to mutilating the late stadtholder's face. ${ }^{40}$

Confraters seide. Houd u meede Gedeputeerde in orde.'

Ibidem. Letter from Fagel to Bergsma, 23 June 1744. 'Maar het smert mij tot in mijn herte, dat ick sie dat buijten noodsaeckelijkheid, door dusdanige maniere van doen, disputen en twisten werden veroorzaakt, die de passien gaende maecke ende tot nadeel van het gemeene beste komen te strecken.'

Mörke, 'Kohärenzstiftung durch Verfahren', 538-542; Thomassen, Onderzoeksgids. Instrumenten van de macht, 392.

\section{Deel I, 111.}

40 NL-HaNA, Fagel, 1.10.29, inv. nr. 583, 'voorval met van Aylva' in de vergadering der Staten-Generaal, 1751, 1 omslag. '[A]ls men die [onderhandeling] niet accordeerde, het soude wesen als of men Sijne Hoogheid een snee door de tronie gaf. $[\ldots][\mathrm{H}]$ ebbende misschien onder het familiair discours de gewoone spreek manier van snee in het aangesigt gebruikt [...].' 
This phrase constituted a severe insult to a man's honour and must have caused shocked reactions. Van Aylva had compared Overijssel's refusal to the violent practice of permanently scarring a man's face-bek opensnijden or rood lintje bezorgen - in this case, to visually and permanently damaging the late stadtholder's honour. ${ }^{41}$ Overijssel filed a complaint against Van Aylva's grave insult, which included a clear description of the atmosphere they expected to prevail in any meeting of the States General. The gentlemen in the States General were to present the position of their principals boldly and fearlessly, without being subjected to insults. ${ }^{42}$ In the end, Van Aylva apologised for his words, and the conflict was omitted from the minutes to bury the discord between Friesland and Overijssel.

How could a slip of the tongue of one delegate trigger a conflict between the States of Overijssel and Friesland? In addition to Van Aylva's allusion to a practice of damaged male honour the political context added gravity to his words. The incident occurred in the tense political moment of an unexpected dynastic discontinuity in the Dutch Republic. ${ }^{43}$ In 1747 , the hereditary Orange stadtholder had been reinstalled to protect the Republic against invading French troops. ${ }^{44}$ William's heir was still a minor in 1751. Now more than ever the provinces needed to maintain harmony in the States General to uphold the political stability of the Dutch Republic. This political context explains why Van Aylva's careless choice of words threatened the harmony and power balance of the Republic as a whole. ${ }^{45}$ On a more general level, the incident affirms that the seclusion of the States General enabled a familiar and harmonious atmosphere. But at the same time, this atmosphere did not appropriate the language of the common people in meetings. Deputies in the States General had to maintain their composure at all times. These two incidents reaffirmed the unspoken norms and values in meetings of the States General. Bergsma's inappropriate request

Herman Roodenburg, 'Eer en oneer ten tijde van de Republiek: een tussenbalans', Volkskundig Bulletin 22:2 (1996) 129-148, see 131, 145.

Gedeputeerden ter generaliteit [mogen] onbeschroomt de ordres en advisen van de Heren Staten hunne competenten vrijmoedig en onbeschroomd [...] uitbrengen, sonder ge-exponeerd te zijn aan sodane insultes [...].'; Tegenwoordige staat I (Generaliteit) 256-257. 'Als alles afgelezen is, worden de Provincien verzogt, zig gereed te maaken, tot het geeven van haare Stemmen. Elk heeft vryheid, om zyn gevoelen te uiten.' en het staatsvormingsproces in de Noordelijke Nederlanden, $16^{\mathrm{e}}-18^{\mathrm{e}}$ eeuw', Amsterdams Sociologisch Tijdschrift 16 (1989) 28-52, see 36.

45 NL-HaNA, Fagel, 1.10.29, inv. nr. 583. '[Friesland] houdende sig $[\ldots]$ onschuldig, aan alle verwijderingen die over deese handelwijse onder het bondgenoodschap mogten ontstaan, bijsonder in deese tijd daar de harmonie en eensgesintheijt, soo ooit ten uittersten nodig sijn, om gesamentlijk het welzijn van de gemeene staat weesentlijk te behartigen.' 
triggered attacks on both his personal honour and that of secretary Fagel. A reconfirmation of honour and the correct hierarchy among the provincial delegates ensued in order to retain the political dignity and legitimacy of the States General's session. Van Aylva's faux pas produced another affirmation of composure during all sessions. Delegates had to refrain from personal, passionate pleas because these endangered the vital political equilibrium between the provinces. Dealing with government business meant that delegates in the States General needed to keep an eye on provincial, personal and general interests and do so in the most respectful manner. Personal honour and political dignity were as much intertwined as they were at stake during meetings of the States General. The plenary sessions of the States General involved not only the process of political decision-making, but also a constant and careful legitimising of the balance among various political and personal interests. Therefore, meetings of the States General were concerned with transmitting political authority as well as with exercising political power. ${ }^{46}$

\section{Batavian parliaments}

The Batavian Revolution brought about major constitutional change. The production and implementation of the first modern constitution significantly changed the nature of political representation. ${ }^{47}$ The National Assembly set out to deal with matters of state in a fundamentally different fashion from the States General. Elected deputies should avoid an all too orderly and quiet meeting, proclaimed Leiden lawyer George Hahn (1761-1822). As representatives of the sovereign Batavian people the National Assembly advocated a lively, public debate instead of the secretive commissions and plenary sessions of the States General. ${ }^{48}$ The voice of the people should resonate in the Assembly hall. For that reason, the ideal deputy was vocal. ${ }^{49}$ Due to the enlarged setting and the presence of the public, the Binnenhof accommodated lively and vigorous political debates on an unprecedented scale. At the same time, however, the three elements characterising meetings

Janiçon, De Republiek der Vereenigde Nederlanden. Deel I, 153. 'Alle deze bepalingen [omtrent bevoegdheid, LL] beletten niet, dat de StatenGeneraal met een groot gezach bekleed zyn, en hunne resolutien hebben doorgaans veel invloed op die van de provincien.'

Joris Oddens, 'Zoeken naar eendracht.

Parlementaire vertegenwoordiging in Nederland tot $1815^{\prime}$, in: Aerts, In dit Huis, 253-278, see 277.

\section{“"Een lam republikeintje als ik." Jacob Hahn,} het achttiende-eeuwse gevoelsdenken en de ordeverstoringen in de Nationale Vergadering', in: Peter van Dam et al. (eds.), Onbehagen in de polder: Nederland in conflict sinds 1795 (Amsterdam 2014) 139-162. Oddens, Pioniers in schaduwbeeld, 114-115. 
of the States General proved resilient. Calmness, harmony and dignity continued to be regarded as favourable qualities of the meeting practice. ${ }^{50}$ Safeguarding personal honour (3) remained of the utmost importance. No matter how lively and passionately a deputy might speak in the interest of the people his words could never harm the honour of another deputy. The Reglement van Orde gave the president official authority to silence an insulting speaker. ${ }^{51}$ After the adoption of the Staatsregeling in April 1798, the National Assembly split up into two Chambers as 'the warm defenders of order' had wished for. ${ }^{52}$ After eighteen months of hard work on the first modern Dutch constitution, the changed setting was marked by statements on the desired modus operandi. They show the resilience of the other two elements characterising the old States General's meeting practice.

First of all, representatives still favoured a subdued atmosphere during meetings to serve the new state properly. They questioned the need for grand gestures and rhetorical elements deployed and advocated by vehement speakers like Hahn. One backbencher remarked that although elaborate rhetorical figures were pretty to see and to listen to in a spectacle, in a representative legislative assembly simplicity alone possessed the grandeur which surpassed all splendour and pomp. ${ }^{53}$ President Pieter Leonard van de Kasteele hoped that the adoption of the Staatsregeling would put an end to 'extensive disputes and personal defences' that had wasted so much time of the National Assembly. ${ }^{54}$ Plain, dignified detachment continued to be seen as the best attitude to deal with matters of state (1). To be composed and to know when to remain silent were advocated as signs of virtuous behaviour of a true representative of the people, behaviour that was preferred to being overly vocal, passionate, personal or stubborn in representing the people's interest. ${ }^{55}$ Journaal van Willem Hendrik Teding van Berkhout (The Hague 1982) 52-53, 78, 99, 117, 124, 136-137, 190. '[S]choonklinkende figuuren der Retorica, fraay zyn te zien en aantehoren in een spectacul, maar niet in eene representative Wetgevende Vergaderinge, alwaar in de discussien en het uitbrengen der advysen de eenvoudigheid alleen behoorde plaats te hebben, welke eenvoudigheid eene grootscheid bezit, die alle pracht en opsmuk te boven gaat.'
54 Dagverhaal Vertegenwoordigend Lichaam [VL], no. 85,31 July 1798,4 . ' $[\ldots]$ geene uitbundige redentwisten zullen ons vermoeijen, en geen personele verdediging onzen tijd verspillen.'

55 Dagverhaal [vL], no. 560, 30 July 1799, 3. Lublink de Jonge: 'Doch het is niet alleen de arbeid zelve, maar vooral de wijze, waarop gy dien hielp verrichten, die $u$ in de oogen uwer Landgenooten eerwaardig moet maaken. Ja, hoe dikwerf zag ik u onder elkanderen wed-yveren $[. .$.$] in het$ oeffenen van een wys zelfbedwang, om wat $u$ persoonlyk zou hebben kunnen grieven, gelaten overtestappen.' See also: Dagverhaal [VL] no. 100, 10 August 1798, 124; Dagverhaal [VL], no. 115, 21 August 1798, 245. 
Secondly, although the plenary meetings of the two Chambers remained accessible to the public, delicate matters were discussed behind closed doors in so-called 'comités-generaal' (2). Plenary public sessions sometimes were nothing more than a repetition of what had been discussed and decided earlier in a 'comité-generaal'.${ }^{56}$ In 1801 , after 38 months in business, French interference ended this bicameral, public parliament prematurely and replaced it with a much smaller, unicameral Wetgevend Lichaam that deliberated behind closed doors until the Incorporation in July 1810.

Despite the National Assembly's wish to go about matters of state in a radically different way than the States General had done, the characteristic elements - reaching political legitimacy through a calm atmosphere (1), secluded sessions (2), and guarding personal honour (3) - of their predecessor continued to characterise the norms regarding the desired meeting practice after 1796. The National Assembly struggled to harmonise its aim for constitutional innovation while respecting the States General's tradition of negotiation. The Restoration regime worked hard to omit or deny everything the Batavian revolution and French Incorporation had achieved from living memory and history. ${ }^{57}$ The regime restored the States General to its former quarters at the Binnenhof. Using the same name, the same rooms, the small and secluded setting all pointed to the purpose of this meeting: appeal to the calm, sober and honourable meeting practice of the States General of the Dutch Republic. ${ }^{58}$

\section{Restoration States General}

Theoretically, the Restoration States General had to have a radically different meeting practice than its namesake in the Dutch Republic. In 1814 the States General returned as a unicameral legislative meeting in a constitutional monarchy. Fifty-five members represented the entire Dutch people instead of their provincial constituencies. They deliberated behind closed doors in such silence however that their sessions equalled venerating Harpocrates. ${ }^{59}$ In 1815 the contrast between the States General of the Dutch Republic and its Restored version became more visible. A bicameral States General that deliberated independently of provincial constituencies replaced the secluded meeting of a small group of representatives of seven sovereign provinces. The

Maurits Cornelis van Hall, Herinneringen van Mr.

Maurits Cornelis van Hall (1787-1815) (Amsterdam 1867) 67.
Henk te Velde, 'Staten-Generaal en Parlement. De welsprekendheid van de Tweede Kamer', in: Aerts, In dit Huis, 167-192, see 167-170.

59 Falck. 1795-1843 (The Hague 1861) nr. 115. Falck to Cornelis Elout, 17 May 1815, 221. 
Second Chamber consisted of 110 members, who deliberated in both French and Dutch and in public.

While the old States General had sought consensus between the provinces to sanction resolutions, the Restoration States General searched for majorities in order to turn royal or government bills into laws. Up until 1795, resolutions had concerned common policies among members of the Union. After 1815, the king and his government proposed bills that were intended to bind the two parts of the realm together. In turn, visible unity among members of the Second Chamber regarding these proposals was believed to have the capacity to unite the new kingdom. The Restoration States General's approval, or polite refusal, signified their trust in the quality of the bills proposed by the king and his government. ${ }^{60}$ MPs from the Northern half of the realm wanted to give their consent to a bill in a solemn atmosphere: to treat a bill with respect enhanced the respectability of the laws in the eyes of the people. ${ }^{61}$ Harmony among members and between Crown and Chamber had replaced harmony among the provinces as the key to assuring obedience of the law or, in other words, to ruling the country effectively and legitimately.

Again, the minutes of the meeting had to be a reflection of the consensual (1) and respectful (3) atmosphere of agreement, rather than a record of various opinions, let alone outright opposition. For that reason, the Second Chamber kept its minutes to itself. ${ }^{62}$ Recording debates would only encourage ambitious members to protest any government proposal, just to have their names inserted in the minutes and to have their chances of reelection increased. ${ }^{63}$ Notwithstanding the availability of modern techniques such as stenography, the States General opted to reinstall the griffie and griffier as their recording officer. The following examples further demonstrate the Oterleek: 'Het onderling vertrouwen tusschen den Koning en de Staten-Generaal, maakt een der sterkste zuilen uit van 's volks welzijn, en levert tevens den besten waarborg op, voor de duurzaamheid van onze grondwettige instellingen.'; HTK 1828-1829, 5 maart 1829, 432. Van de Kasteele: '[...] cette mesure risque de compromettre la dignité de la Chambre, car si le Roi, ce qui est très-probable, refuse d'accepter une telle communication et renvoie les pièces communiquées, alors la dignité de cette Assemblée est compromise, cela donnera lieu à des difficultés graves et rompra nécessairement I'harmonie entre cette Assemblée et le Chef de l'État.'; See also: Ineke Secker, 'Onder koninklijke voogdij. De Tweede Kamer vindt haar plaats binnen de constitutionele monarchie', in: Aerts, In dit Huis, 279-304, see 289-291.

61 HTK 1819-1820, 29 March 1820, 150 (Van Lynden); HTK 1829-1830, 14 December 1829, 131-135; Brieven van Falck, nr. 125. to David van Lennep, 26 February 1817, 233; Johan Zwaan (ed.), Groen van Prinsterer Schriftelijke Nalatenschap. Achtste deel. Bescheiden, deel II, 1821-1842, 219.

62 HTK 1815-1816, 28 December 1815, 47; 4 January 1816, 58-59; Bijl. xX, 105; HTK 1821-1822, 7 August 1822, 464; HTK 1823-1824, 11 May 1824, 179. In 1843 the minutes of the comité-generaal recorded discussions more extensively. NL-HaNA 2.02.22 Tweede Kamer der Staten-Generaal, inv. nr. 241, 26 January 1843.

63 HTK 1815-1816, 4 January 1816, 59. 
continuity of the three elements. Confined, constructive and composed negotiations and protection of personal honour remained preconditions to achieve the objectives of the States General.

In 1827, Northern member Bijleveld described his duties as representative in almost the exact same words the States of Overijssel had used in 1751. As a member of the Second Chamber he felt obliged to express frankly his feelings in plenary discussions, awaiting the better judgement of his colleagues. ${ }^{64}$ In other words, every deputy should be able to speak his mind without fear of being insulted or ridiculed. For the same reason, Northern member De Jonge had felt the urge to speak up in the plenary session in 1821 . In a secluded preparatory session, a colleague had condemned De Jonge's position as foolish and miserable. ${ }^{65}$ De Jonge used the public session to demand that this fellow MP treat him with more respect, no matter how their views might differ. These examples show that - like the preparatory sessions of the Old Regime States General - the secluded, small-scale sessions (2) were perhaps more familiar in atmosphere, yet members had to maintain their composure (1) in order to show respect (3). ${ }^{66}$ Frankness and composure, personal and political interests were still intertwined in the States General after 1815 . Furthermore, the plenary session continued to be the place where the required harmonious and honourable atmosphere could be reaffirmed. In any other setting, the ideal tone of voice for an MP was also frank and honest, but at the same time straightforward and polite. ${ }^{67}$

Prior to 1815 , the Southern and Northern provinces had witnessed different constitutional developments. These divergent trajectories can explain why the Southern members had other views on what and how they

64 HTK 1826-1827, 2 February 1827, 155. Bijleveld: 'Als lid dezer tweede Kamer van de Staten-Generaal ben ik geroepen om, bij dat gemeen overleg, ook voor mijne gevoelens onbeschroomd, behoudens beter oordeel, uit te komen en openlijk aan den dag te leggen.'

Universiteitsbibliotheek Leiden, Collectie Luzac, BPL 1562 nr. 1-16o. Lodewijk Luzac to Cornelis Jacobus van Assen, 20 May 1829. '[...] in die commissie zeer aangenaam bijeen geweest. Wij verschillen soms zeer sterk in onze opinien, doch kibbelen nooit. De deliberatien gaan zeer geleidelijk voort, op eene zeer beleefde wijze, en nooit nog heeft iemand zich bij ons driftig gemaakt.'

Cornelis Johannes van Heusden, Proeve over de keuze van volksvertegenwoordigers in het Koningrijk der Nederlanden (Gorichem 1821) 12; Brieven van Falck, nr. 16o. to D.J. van Lennep, 18 January 1828 , 276. 'De toon en het beloop der discussien in de Tweede Kamer hebben mij over het algemeen zeer wel bevallen. Er vormt zich [...] een publieke geest zooals wij dien noodig hebben, opdat onze regeringsvorm de wenschelijke stevigheid erlange; eerbied voor het Souverein gezag en echter bescheidene vrijmoedigheid in het beoordelen en bestrijden van deszelfs daden; zoo dit op den duur vereenigd blijven kan (en waarom zoude het niet?) zal de natie aan [...] Hollandsche Gedeputeerden die het op dien voet zullen hebben gesteld, oneindig grootere verplichting hebben, dan aan de schijnbaar forssere oppositie die het Zuiden oplevert [...].'; Van Zanten, Schielijk, 141-147. 
should represent in the Second Chamber. ${ }^{68}$ Since 1794 the former Austrian Netherlands had been part of the French state. No Southern member entering the Second Chamber had been part of the Estates Assembly that met with the Habsburg overlord. The Belgian Revolutions (1787-1793) had not led to the establishment of a National Convention. ${ }^{69}$ Instead, Southern members had gained experience in office from their employment in the French Departmental administration. Moreover, twelve Southern members had been members of the French Assemblée Nationale. ${ }^{70}$ Their Northern colleagues' experience with national political representation was of a different sort. Eight members had been deputies in the Old Regime States General. ${ }^{71}$ After 1795, the Batavian Revolutionaries had had the liberty to form their own political institutions, within the boundaries set by their French 'custodians'. ${ }^{72}$ The Second Chamber counted eight former members of the secluded and unicameral Wetgevend Lichaam (1801-1810). ${ }^{73}$

Southern members of the Second Chamber differed from their Northern colleagues on how they went about their business as representatives. No doubt inspired by the French parliamentary orators, Southern members used passion and vigour in their speeches to convey the voice of the people. ${ }^{74}$ In contrast, Northern members preferred calm, detached and reasonable discussions to rhetorical theatre. ${ }^{75}$ Southern members made it very clear to their Northern colleagues that it was the voice of the people that should

69 Janet Polasky, Revolution in Brussels (1787-1793) (Brussels 1982) 253-254, 267-269. naar de sociale en politieke achtergrond van de personen die zitting hadden in de Staten-Generaal van het Verenigd Koninkrijk der Nederlanden (18151830) (unpublished research report Leiden 1977) 72-77. C.Ph. van Lidth de Jeude, W.N. de Pesters, F.P.G. van Schuylenburch, J.F.W. van Spaen, G.F. Fontein Verschuir, J.E.N. van Lynden.

Annie Jourdan, 'The Netherlands is the Constellation of the Eighteenth-Century Western Revolutions', European Review of History: Revue européene d'histoire 18:2 (2011) 199-225, see 208-209; Mart Rutjes, 'Het belang van het volk. De politieke cultuur van het algemeen en het wantrouwen tegen collectieve belangenbehartiging tijdens de eerste Nederlandse democratie, 1795-1801', in: Liesbeth Geevers and Griet Vermeesch (eds.), Politieke belangenbehartiging in de vroegmoderne Nederlanden. De rol van lobby, petities, en officiële delegaties in de politieke besluitvorming (Maastricht 2014) 139-154. DOI: https://doi.org/10.1080/13507486 .2011 .555949 .

P.A. van Boetzelaer, G.A.M. van Bommel, J. Busch, J.P. van Wickevoort Crommelin, S.J. van Heiden Reinestein, L.F.J.J.J. van Sasse van Ysselt, F.P.G. van Schuylenburch, J.F.W. van Spaen. Henk te Velde, Sprekende politiek. Redenaars en hun publiek in de parlementaire gouden eeuw (Amsterdam 2015) 69-82. Guillaume Groen van Prinsterer, Over volksgeest en burgerzin (Leiden 1829) 28. 'Dat zich [...] in de Tweede Kamer der Staten-Generaal meermalen eene tegenstelling tusschen Noordelijke en Zuidelijke Leden openbaart, moet niet aan den aard der Zuid-Nederlandsche bevolking, slechts gedeeltelijk aan welligt schijnbaar tegenstrijdige 
resonate in their speeches. ${ }^{76}$ Perhaps Southern members' closer proximity to revolutionary France and to the people in general - as officials working in departmental, rather than national, administrations - made them more prone to represent the people's voice in the Second Chamber. ${ }^{77}$ They were certainly much less interested in simply giving consent to a bill. Instead they considered it their duty to assess publicly and critically whether a bill matched the people's wishes. ${ }^{78}$ An overly calm and quiet Second Chamber even brought back memories of despotism and the Old Regime. ${ }^{79}$ Southern members were seriously annoyed by Northern members who constantly disqualified their criticism of bills as blunt attacks on the authority of King William I. Southern mayor Ange Angillis for example explained that an MP who vigorously defended the people's interests would necessarily become an equally dauntless defender of the throne. ${ }^{80}$

The young Charles de Brouckère, Jr. (1796-1860) was the most rigorous, passionate and eloquent Southern member of the Second Chamber. Amidst the mass petition waves in late November 1828, this fierce liberal proposed to abolish the existing restrictive press regulations. ${ }^{81}$ The proposal

belangen, maar voornamelijk aan de opvoeding en denkwijze der hoogere standen in België toegeschreven worden. De Hollanders staan dikwijls in de Vergadering geheel op zich zelven. Zij willen niet zóó spoedig, zóó krachtig, zóó heftig als de meeste Zuidelijke leden vooruit.'; See also: Marnix Beyen and Henk te Velde, 'Passion and Reason. Modern Parliaments in the Low Countries', in: Pasi Ihalainen, Cornelia Ilie and Kari Palonen (eds.), Parliament and Parliamentarism. A Comparative History of a European Concept (New York and Oxford 2016) 81-96, see 9o; Johannes van den Berg and Jacob Vis, De eerste honderdvijftig jaar. Parlementaire geschiedenis van Nederland, 17961946 (Amsterdam 2013) 222.

Marnix Beyen and Rik Röttger, 'Het streven naar waardigheid. Zelfbeelden en gedragscodes van de volksvertegenwoordigers', in: Emmanuel Gerard et al. (eds.), Geschiedenis van de Belgische Kamer van Volksvertegenwoordigers (Brussels 2003) 336-383, see 354-356; Henk de Smaele, 'Eclectisch en toch nieuw. De uitvinding van het Belgisch parlement in 1830-1831', Bijdragen en Mededelingen betreffende de Geschiedenis der Nederlanden, 120:3 (2005) 408-416, see 410, 413 .
77 Meerts, Kamerleden 1815-1830, 72-77.

78 HTK 1826-1827, 20 December 1826, 57. Fallon: '[u]n représentant de la nation ne peut voter un budget de confiance; il doit donc s'assurer si toutes les demandes d'argent sont suffisamment justifiés par la nécessité ou l'utilité des dépenses, qu'elles sont destinées à couvrir.' HTK 1828-1829, 2 December 1828, 115, 123; Le Hon: '[L]e calme du despotisme, c'est le silence de tous; celui de l'aristocratie, c'est le silence du plus grand nombre dans l'intérêt du plus petit; le calme d'une monarchie constitutionnelle et représentative, c'est l'action constante des opinions et des intérêts dans la sphère de l'ordre.'; See also: HTK 1828-1829, 3 March 1829, 408.

80 HTK 1829-1830, 17 December 1829, 169. Angillis: ‘[...] tel député qui défend aujourd’hui les intérêts du peuple avec chaleur, deviendrait au besoin le défenseur non moins intrépide des intérêts du trône.'

81 HTK 1828-1829, 28 November 1828, 53-57; Gijsbert Karel van Hogendorp, Bijdragen tot de huishouding van Staat in het Koninkrijk der Nederlanden verzameld ten dienste der Staten-Generaal, v (Zaltbommel 1855) 58. 
triggered chaotic and vehement debates, which alienated Northern and Southern members and hence jeopardised the unity of the realm. Equally eloquent but less vehement, Le Hon tried to restore harmony among the members in a dignified speech. All members supported the freedom of press despite the opposing views between North and South regarding De Brouckère's proposal. ${ }^{82}$ But apart from Leopold van Sasse van Ysselt, Northern members voted unanimously against De Brouckère's proposal. ${ }^{83}$ In Northern eyes, their refusal to abolish an existing law was seen as a display of apt composure (1) and genuine independence, whereas the Southern supporters were dismissed as being driven by their longing for popularity or by their fear of newspapers' retaliation. ${ }^{84}$

Southern members in the First Chamber, or Senate, did not support the behaviour of their compatriots in the Second Chamber. On the contrary, in 1821 President of the First Chamber Charles Count de Thiennes de Lombise (1758-1839) complained about the lack of 'knowledgeable moderation' in the Second Chamber. ${ }^{85}$ According to De Thiennes, the habit of members responding to encouragements from the public stands was evil. His colleague F.F. de P.H.J. Baron d'Anéthan (1743-1824) added that his lack of oratorical talent did not prevent him from fulfilling his duty as a member of the First Chamber. Eloquence was superfluous because simply telling the truth sufficed to touch the heart and enlighten the spirit of the meeting. ${ }^{86}$

Liefmans and other Southern members of course felt unjustly accused by De Thiennes' and d'Anéthan's denunciations of passionate debate in the Second Chamber. ${ }^{87}$ The conventions of appropriate behaviour followed by the high nobility in the First Chamber stood in contrast to the Southern members' conventions in the Second Chamber. The latter saw no harm in letting the public in the Chamber inspire them to speak up as their representatives. In general, therefore, Southern members in the Second Chamber disliked the fact that the Second Chamber regularly converted itself into 'comité-generaal', which meant that the public had to leave the assembly hall. ${ }^{88}$ They wondered why those sessions could not be open to the public as well, since-according to Southern standards at least - those sessions were as decent and calm as plenary meetings. Nevertheless, the majority of members present preferred to discuss behind closed doors (2). After the Southern members had left the Second Chamber in 1830, the States General could once again give in to their inclination to support government stability in meetings characterised by the Kamerzittingen van 1828-1831', 160-161. Lennep. 12 January 1829, 279.
85 HTK 1820-1821, 30 June $1821,505$.

86 Ibidem, 508.

87 HTK 1821-1822, 22 December 1821, 48; See also HTK 1821-1822, 14 May 1822, 157.

88 HTK 1820-1821, 10 February 1821, 16o; Ibidem, 12 February $1821,168$. 


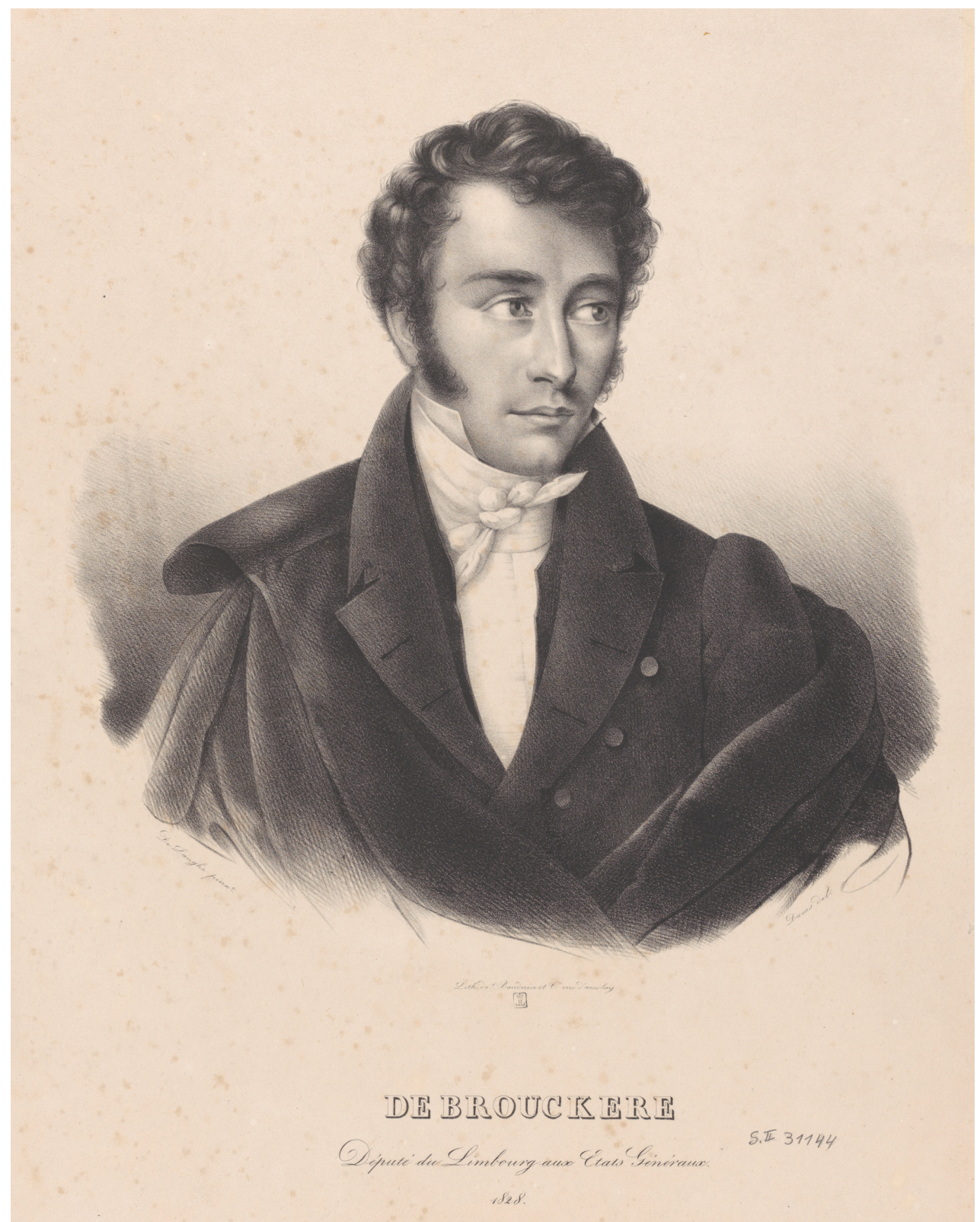

$\Delta$

Charles de Brouckère Jr. (1796-1860), member of the States General on behalf of Hainaut. Royal Library of Belgium, Brussels. 
three elements: in a pragmatic, composed and harmonious atmosphere, ${ }^{89}$ and preferably behind closed doors. ${ }^{90}$

\section{Conclusion}

When the Southern members entered the States General in 1815 , they met in a Second Chamber that cherished a composed, secluded, pragmatic, governmental way of fulfilling its duty as representative assembly. This article presents the clash regarding conventions of proper behaviour between members representing Northern and Southern provinces as evidence of continuity in the meeting practices the States General had witnessed since the Dutch Republic. The longterm history of meetings in the States General reveals the continuity of the Northern ideal of pragmatic, secluded, and dignified representation aimed at consensus among members, Chamber, king and government that dominated the code of conduct in the States General after 1815 . The predominantly Northern mores and habits aimed at consensus did not accommodate the critical remarks and elaborate style of Southern representatives.

The passionate and critical tone of Southern members would have fitted perfectly with the conventions of the National Assembly. However, unfortunately for Southern members like Le Hon and Liefmans, the appreciation for passion and vigour in the National Assembly was not something their Northern colleagues were keen on restoring. The introduction of the first modern Dutch constitution had not changed the norms supporting the practices of how representatives at the Binnenhof should deal with government business in order to support the legitimacy of the regime. The desired meeting practice the Dutch States General had cherished since the Dutch Republic again proved resilient despite the apparent changes to the States General in the constitution of 1815 . Not surprisingly, the first Belgian parliament developed a radically different style of meeting than that of the States General after $1830 .{ }^{91}$ The disparity in the

89 HTK 1835-1836, 11 December 1835, 91. 'Na den opstand (1830, LL) heeft hij altijd voor de budgets gestemd, omdat hij begreep, dat wat het zwaarste was, het zwaarste moest wegen; dat eensgezindheid van binnen ontzag van buiten zoude verwekken'; see also HTK 1836-1837, 9 March 1837, 67 (Van Dam van Isselt); HTK 18421843, 2 October 1843, 673. Van Panhuys: '[...] het gevoelen dier meerderheid eerbiedigen. Hij acht zulks parlementair en nuttig voor het land; hij gelooft dat daardoor de eensgezind in deze Vergadering bevorderd en het aanzien en gezag buiten de Kamer voor hetgeen hier wordt tot stand gebragt vermeerderd zal worden.'

90 HTK 1841-1842, Bijl. III, 'Herziening van het Reglement van Orde (Memorie van Luzac over de werking van het nieuwe Reglement)', 62.

91 De Smaele, 'Eclectisch en toch nieuw', 408-416; Els Witte, 'De Grondwet', 15-44. 
way members of the Second Chamber treated bills undermined the legislative efforts to consolidate the United Kingdom of the Netherlands. Therefore, understanding why this clash occurred adds perhaps another reason to the complex set of factors contributing to the disintegration of this Restoration state. ${ }^{92}$ Future research could compare how other Restoration parliaments dealt with their Old Regime tradition and investigate the consequences for modern political history and politics. ${ }^{93}$

The governmental attitude of the Dutch parliament is what struck foreign observers of meetings of the States General. ${ }^{94}$ But now that we have seen the long tradition of meeting in the Dutch States General, we understand better why the Dutch parliamentarians - up to the present day - have been preoccupied with cementing broad coalitions, which ensure consent for government proposals. This article has shown why meetings of the States General - prior to and after 1795 - deliberately chose to deal with government business in a composed manner and in a secluded environment. Deliberating over consent on either a resolution or a bill had to take place in an orderly manner in order to ensure the willingness of the provinces or the Dutch people to obey it. The continuity of this meeting practice in turn ensured the States General's ability to support the legitimacy of the Dutch government. This principle of government and the matching attitude of deputies ensured the States General's remarkable continuous existence during the Dutch Republic and the moderate meeting practice entertained by its members. With these preconditions of an orderly discussion as its guiding principles the States General lived through revolutionary storms and constitutional shifts without radically changing its style or practice of representation after 1795 . Willem I (1815-1830)', Bijdragen en Mededelingen betreffende de Geschiedenis der Nederlanden 112:1 (1997) 502-516, see 510-513; Marnix Beyen, 'Terug naar het oude Vaderland. De desintegratie van het Verenigd Koninkrijk', in: Remieg Aerts et al. (eds.), Het (on)verenigd Koninkrijk 1815-1830. Een politiek experiment in de Lage Landen (Rekkem 2015) 140150, see 148-149. DOI: https://doi.org/10.18352/ bmgn-Ichr. 4570.

The Polish Sjem, for example, inherited a tradition of parliamentary opposition. Andrezj Nieuwazny,
'The Polish Kingdom (1815-1830): Continuity or Change?', in: David Laven and Lucy Riall (eds.), Napoleon's Legacy. Problems of Government in Restoration Europe (Oxford 2000) 115-128, see 118, 125 .

94 Johannes van den Berg, 'Een parlement in vier gedaanten', in: Wim van Noort, Jan Laurier and Marta Dozy (eds.), Organiseren op een breukvlak. Zes opstellen over organisaties in verleden, heden en toekomst (Amsterdam 1993) 65-79, see 75-76. 
Lauren Lauret (1991) is currently preparing a dissertation on the continuity of meeting practices in the Dutch States-General (c. 1750-1850) at Leiden University. She studied History in Nijmegen (RU) and Münster (WWU) (cum laude). Her research focuses on the norms, values and practices of early modern political representative institutions. Publication: (with Remieg Aerts) ‘De gekroonde feniks. Karel II Stuart en de interpretatie van het koningschap in de zeventiende eeuw', in: Peter Rietbergen (ed.) Sacrale macht. Religie en politiek in vroegmodern Europa (Nijmegen 2015) 125-147.

Email: I.b.lauret@hum.leidenuniv.nl. 